\title{
Pediatric journals of the Southern Cone. Similarities and differences
}

On October $13^{\text {th }}$ of this year, the XXII Meeting of Editors of Pediatric Journals of the Southern Cone Pediatric Societies was held in Fortaleza, Brazil.

This meeting, that has been held annually for 20 years, takes place in an environment of camaraderie, cordiality, commitment and desire for continuous improvement. The exchange of experiences in settings that vary from country to country displays the wide range of possibilities that scientific publications have, inevitably linked to their particular historical contexts.

On the one hand, a common technical language is used. For many years, thanks to the initiative of the editors of the main scientific journals who meet in Vancouver, Canada, a theoretical basis, Recommendations for the Conduct, Reporting, Editing, and Publication of Scholarly Work in Medical Journals ${ }^{1}$ was developed. While these recommendations are not based on scientific evidence, we must recognize that they have helped to give consistency to the style of scientific writing, and that they are useful for any type of presentation and contain the basic guidelines that are necessary to write and publish clear, accurate and brief works, which are the three great secrets of the scientific publishing world.

On the other hand, seeing a wide range of nuances in pediatric journals has been enriching. One might think that the ideal situation is to develop content similar to that of first-class international journals. However, this is not the case.

Editors of official scientific publications of the pediatric societies from Uruguay, Paraguay, Chile, Brazil and Argentina attended the meeting. The representative of Bolivia could not attend the meeting. The meeting was held within the framework of the $38^{\text {th }}$ Brazilian Congress of Pediatrics, the $15^{\text {th }}$ Brazilian Congress of Teaching and the $10^{\text {th }}$ Brazilian Congress of Research. One of the scheduled activities was a round table focused on the main scientific journals of Brazil. Editors of journals of scientific societies, educational communities and healthcare centers participated.

Each journal had different objectives; there was place for research, teaching, the preservation of the historical heritage of each institution, deep reflection on human values and life stories of patients and professionals.

Healthcare, teaching and research are three pillars that should always be present in the professional life, and scientific publications are the meeting point of these three components. The purpose of research is to acquire new knowledge; research findings are published to be disseminated; one reads in order to learn, to teach, to improve our professional practice and to formulate new questions that will trigger future research. Truth is transient. Acquiring knowledge should never stop.

The role of editors requires great responsibility. Scientific research provides countless data, but some of them lack the methodological support that can render them valid. The editorial task is to communicate state-of-the-art, relevant and reliable contributions to the community in order to advance in the endless search for knowledge.

But, to develop knowledge, resources are needed, and scientific publications are part of the approach to obtain those resources. It is more likely that renown researchers are supported and have their papers published in international, first-class journals.

"First class" could be defined in different ways but in order to do it from a quantitative and measurable standpoint, bibliometric indicators should be used; that is, measures of the importance of a publication by means of its visibility, number of citations of its articles, how fast publications are quoted by other researchers, etc. The best known indicator is the impact factor, with strengths and weaknesses, but chosen by research support agencies to assess the projects that apply for resources. ${ }^{2}$

It seems it would be ideal that each scientific community (due to its geographical location or specialization) had a journal with a high impact factor. Developing such publication implies choosing this option and leaving others aside. The best articles (for their scientific value and editorial quality) will be accepted for publication. Journals with a high impact factor accept approximately $10 \%$ of the articles they receive. The remaining $90 \%$ should seek other ways of dissemination. And this is where the diversity of scientific publications and the wide array of options are understood.

To aspire to a publication in a first class journal is very challenging. The editorial policy of these journals might seem "cruel" to authors whose articles are rejected. But this rejection should be interpreted differently. It is not an act of cruelty nor a failure; rejection should not be "ad hominen" as if it was a personal disqualification; nor should an author expect that the article will be accepted because of his/her prestige or because he or she collaborated to the journal in former occasions.

The rejection of an article simply means that it does not meet the requirements that said scientific journal has established as necessary for the editorial process to continue. The reasons stated in the review are valuable resources to improve the article and achieve its publication in a different scientific journal. $^{3}$ 
Another emerging subject was that related to resources needed to maintain a scientific publication, in some cases supported by the Scientific Societies to which they belong, in others, by the advertising of medicines, supplies or medical equipment, and in some others even by the contribution of the same authors who want to have their articles published.

The transition from paper publications to electronic formats, for ecological, practical and economical reasons is a reality, ${ }^{4}$ but it also implies a challenge to obtain resources through advertising. Paper lasts, it can be seen. Electronic publications seem short-lived. However, society is heading toward this change, toward new ways of communicating.

Free access to scientific knowledge is a universal claim. Open access journals fulfill this "solidarity" role of sharing knowledge with the community. But material aspects are part of daily life. Although it is not a pleasant subject, in economically difficult situations, it may be possible that authors are asked for their contribution to face the costs related to the editorial process or, for example, the translations into other languages.

As we can see, a scientific publication is a craftwork tailored to the community it belongs to. That is what defines the extent of its objectives, but one should always aspire to excellence, out of respect for the work of the authors and editors and the trust that readers place in it.

At the end of the meeting of editors, we all felt that we had received a lot, perhaps much more than what we were able to give back by sharing our experiences, difficulties, ways of overcoming them, future projects and new challenges. Each of the journals has paved the way for the rest. We hope to meet next year with the same enthusiasm and commitment.

Norma Elena Rossato, M.D. Associate Editor

http:/ / dx.doi.org/10.5546/ aap.2018.eng.2

To cite: Rossato NE. Pediatric journals of the Southern Cone. Similarities and differences. Arch Argent Pediatr 2018;116(1):2-3.

\section{REFERENCES}

1. ICMJE. Recomendaciones parala preparación, presentación, edición y publicación de trabajos académicos en revistas médicas. Rev Esp Salud Pública. 2017;91. [Accessed on 1103-2017]. Available at http://www.icmje.org/recommendations/ translations/spanish2016.pdf

2. Rueda-Clausen Gómez CF, Villa-Roel Gutierrez C, RuedaClausen Pinzón CE. Indicadores bibliométricos: origen, aplicación, contradicción y nuevas propuestas. MedUNAB 2005; 8(1);29-36. [Accessed on 11-03-2017]. Available at: http://132.248.9.34/hevila/Medunab/2005/vol8/no1/5.pdf

3. Ferrero F. Publicación científica: ¿Cómo enfrentar el rechazo? Arch Argent Pediatr 2015;113(2):98-100.

4. Gómez Rodríguez G, Gallo Estrada MC. El proceso de transición de las revistas académicas: de impreso a digital. Paakat: Revista de Tecnología y Sociedad. Año 6, Núm. 10, marzo-agosto 2016. [Accessed on 11-03-2017]. Available at: http://www.udgvirtual.udg.mx/paakat/index.php/paakat/article/ view/265

\section{Editors of biomedical journals and the disclosure of their own conflicts of interest}

Continuing with the topic of conflicts of interest related to scientific publications, recently, an article by Liu et al. ${ }^{1}$ was published in the British Medical Journal (BMJ) regarding the financial relations of medical journal editors. According to this investigation, in the USA, approximately half of the editors of 52 prestigious medical journals received financial payments from the pharmaceutical industry and medical device manufacturers in 2014.

Recently, in a special article ${ }^{2}$ published in Argentine Archives of Pediatrics (Archivos Argentinos de Pediatria) with regard to a publication supplement in the Journal of the American Medical Association (JAMA) devoted to conflicts of interest, the complex topic of conflicts of interest was extensively approached in different scenarios: real conflicts or perceived by physicians, investigators, professional associations, scientific societies, biomedical journals among other stakeholders.

The objective of the observational and retrospective study by Liu et al., ${ }^{1}$ was to estimate the financial payments from industry to US journal editors. Two medical editors (editors in chief or associate editors) were selected from 52 journals drawn from 26 specialties, with a high impact factor for their specialty. General and research payments received from pharmaceutical companies and medical device manufacturers were collected and examined in 2014, through the Open Payments databases. Additionally, the magnitude of such payments was compared across journals and by specialty, and journal websites were also reviewed 